\title{
Development of a Framework for Identifying Highway Projects for Private-Public-Partnership Financing
}

\author{
Kopikah Tharmakulasingham and H.R. Pasindu
}

\begin{abstract}
In many cases, Public Private Partnership (PPP) projects are looked upon as a sceptical phenomenon due to the involvement of risk factors. However, in order to reduce the financial burden on the government, it is essential to undertake PPP projects. Absence of a supporting framework was identified as one of the key issues in accelerating PPP projects in Sri Lanka. A review was performed in this study to identify and develop the screening criteria in Sri Lanka. As part of the study, criteria which are used in other countries, and World Bank for selection of PPP projects were collected. A Multi Attribute Analysis was used in the research. The criteria identified from other countries are subpackaged under Demand, Financial, Risk and Scale categories.

A questionnaire survey was conducted among highway experts. The ranking of subpackage criteria, top six preferred criteria, and their scores by nine respondents were collected. The preliminary screening criteria were identified using Garrett ranking technique by selecting a single criterion from each subpackage. Based on the guidelines of other countries the percentage responses, and scores for the top six preferred criteria, nine criteria were recommended for secondary screening. Financial viability of a project was identified as the topmost criterion in project screening. Further, PPP candidate nature of 10 selected highway projects was analyzed based on the secondary screening criteria. Due to lack of available information,: financial viability, economic development, traffic congestion reduced from the projects, roles of the road in network and project cost were used for the comparison of projects. Port Access Elevated Highway was received the highest total score from the secondary screening.
\end{abstract}

Keywords: Public private partnership, Multi attribute, Screening criteria, Garrett ranking technique

\section{Introduction}

1.1 Background

After the end of three decade war in the country, the Government of Sri Lanka (GOSL) has undertaken rapid highway construction projects to increase the connectivity of the country and boost the economy by connecting major cities and economic hubs. As a traditional practice reserves, loan or grant funds are used for financing purposes. However, when analyzing the debt to gross domestic product (GDP) ratio of Sri Lanka, it has reached a value of $82.9 \%$ for the year 2018 .

Debt to GDP is one parameter looked upon as one country's ability to payback future payment to the investors. So, increasing Debt to GDP ratio has increased the risk for the lenders and borrowing in the future will be difficult.

Therefore, alternative financing methods should be considered for public investment projects. Public Private Partnership (PPP) is used in many countries and this alternative method can be considered for highway construction financing.

\subsection{Problem Statement}

Selection of viable PPP projects is a critical phase in PPP development and there should be a framework to support the PPP process in the country. One of the key constraints for PPP development in Sri Lanka is over reliance on unsolicited proposals. Not only in Sri Lanka, in many countries, there are no proper guidelines to screen Highway PPP projects. So, it is crucial to identify key factors to develop a screening tool by considering successful practices of other countries.

Eng. K. Tharmakulasingham, AMIE (SL), B.Sc. Eng. (Hons) (Moratuwa), Post Graduate Student, Department of Civil Engineering, University of Moratuwa.

Email:kopikah@gmail.com

Eng. (Dr.) H.R. Pasindu, MIE (SL), Ph.D, B.Sc. Eng. (Hons) (Moratuwa), Senior Lecturer, Department of Civil Engineering, University of Moratuwa

Email: pasindu@uom.lk 
As the preparation for PPP projects demands financial and human resources, it is the key to screen good candidate projects for PPP to utilize limited resources. This research will mainly focus on Road projects.

\subsection{Objective of the Study}

Develop a framework to assist identification, selection and prioritization of projects from pipeline to finance under PPP and create a list of viable PPP projects.

Under the main objective, following subobjectives are identified.

1. Develop Criteria to identify candidate PPP projects.

2. Compare completed, ongoing and future projects in Sri Lanka for the viability as a PPP project.

\section{Literature Review}

2.1 PPP Project Selection Methods in Sri Lanka

In Sri Lanka, the National Agency for Public Private Partnership (NAPPP) uses a two step process for screening projects. In the first step, the following five filters are used to shortlist the projects (Redup, 2019).

- $\quad$ Project readiness filter

- Investment cost filter

- Public investment plan filter

- PPP definition filter

- Sector exclusion project

In the second step, the following nine criteria are used for the second step of project screening (1).

- GoSL Priority

- Management/ Technical Gaps and Service Levels

- $\quad$ Line Ministry Readiness

- Status of Project Preparation

- Project Implementation Timeline

- Project Feasibility

- Financing

- Private Sector Appetite

- Availability of Information

\subsection{Identification of Criteria for PPP Development}

In order to identify criteria for selection of road projects for PPP development, criteria which have been considered for the similar purpose were collected from USA (US Department of Transportation, Virginia Transportation, Commonwealth of Pennsylvania), Pakistan, Philippines, and World Bank guidelines.

\section{Methodology}

In this research, selection criteria were identified from literature review from specific guidelines used by other countries. The criteria were further shortlisted using the questionnaire survey analysis. In the next step, the finalized criteria were compared with past, ongoing and future Sri Lankan projects.

\subsection{Selection of Criteria}

\subsubsection{Multi Attribute Analysis}

Multi-attribute analysis is a method used to select a project based on a criteria package. There can be sub criterion packages under main packages. Weightages can be given to main criteria and sub criteria. There should be maximum attainable score to each criterion. Each project can be evaluated against the criteria and a total score can be calculated. This method is developed based on similar research on PPP to Select concessionaire by Zhang (2).

\subsubsection{Selection of Appropriate Criteria for each Sub-package}

\subsubsection{Demand Related Factors}

The following five criteria were selected under demand sub-package.

1. Urgency of the project to reduce congestion

2. National, regional economic development

3. Safety needs

4. National, regional social benefits

5. Role of the road in network development

\subsubsection{Financial Related Factors}

The following four criteria were selected under financial sub-package.

1. Financial viability

2. Long range revenue potential from the project 
3. Impact of project on viability of existing toll roads

4. User pricing (Toll rates)

\subsubsection{Risk Related Factors}

The following seven criteria were selected under risk sub-package.

1. Value for money from the project

2. Transfer of significant operational \& management risk to private team

3. Design of the project to achieve best practice by PPP

4. Cost and revenue risks

5. Land acquisition

6. Resettlements

7. Meeting environment safeguards

\subsubsection{Project Scale Related Factors}

The following four criteria were selected under project scale sub-package.

1. Project cost

2. Project functional scope

3. Public agency capability in funding the project

4. Project design and construction complex

\subsection{Questionnaire Survey}

Questionnaire survey method was used to verify the criteria and its relevancy to Sri Lanka, shortlist crucial preliminary and secondary screening criteria and find out the score of the key criteria. One of the major problems was that very limited number of participants were available to get these details.

The questionnaire survey was conducted among nine respondents from Road Development Authority (RDA), National Agency for Public Private Partnership (NAPPP), and private consultants. Responses were collected from experts who are experienced in both highway and PPP projects.

As a first step of questionnaire survey, ranking was carried out for each subpackage. Respondents were asked to rank all criteria under the subpakage. For example, the respondents were requested to rank 1 to 5 for each criterion under demand subpackage. In order to find out the preferred criterion, Garrett's ranking technique was used (3). Using Garrett's ranking technique all the ranks were converted to score values. The following formula and Garrett's table were used to convert ranks into scores.

Percent Position $=100\left(R_{i j}-0.5\right) / N_{j}$

Where;

Rij= Ranked given for $i^{\text {th }}$ criterion by $j^{\text {th }}$ respondent

$N j=$ Number of criteria ranked by $j^{\text {th }}$ respondent

Thus, a most significant criterion to represent each subpackage can be selected.

In the next step, to identify the importance of each criterion, a 1-10 numerical rating scale is used. This 10-point scale used to indicate the following importance of the criteria in decision making. One (1) implies least significant for the decision making while Ten (10) implies most significant for the decision making.

\subsection{Case Study}

Ten (10) Sri Lankan expressway projects were selected. The feasibility study report of these projects was used to collect details about the projects. Further, interviews with directors and project engineers were carried out.

4. Identifying Preliminary and Secondary Selection Criteria from Questionnaire Analysis

\subsection{Data Analysis}

\subsubsection{Demand Related Criteria}

The purpose of the question is to select a criterion to better represent demand of the project. A Rank from 1 to 5 was assigned for most important to least important criterion by respondents. Figure 1 shows the percentage of ranks given by nine respondents for each demand related criterion. The following abbreviations are used in Figure 1.

Urgency: Urgency of the project to reduce congestion

Economic: National, regional economic development

Safety: Safety needs

Social: National, regional social benefits

Network: Role of the road in network development 


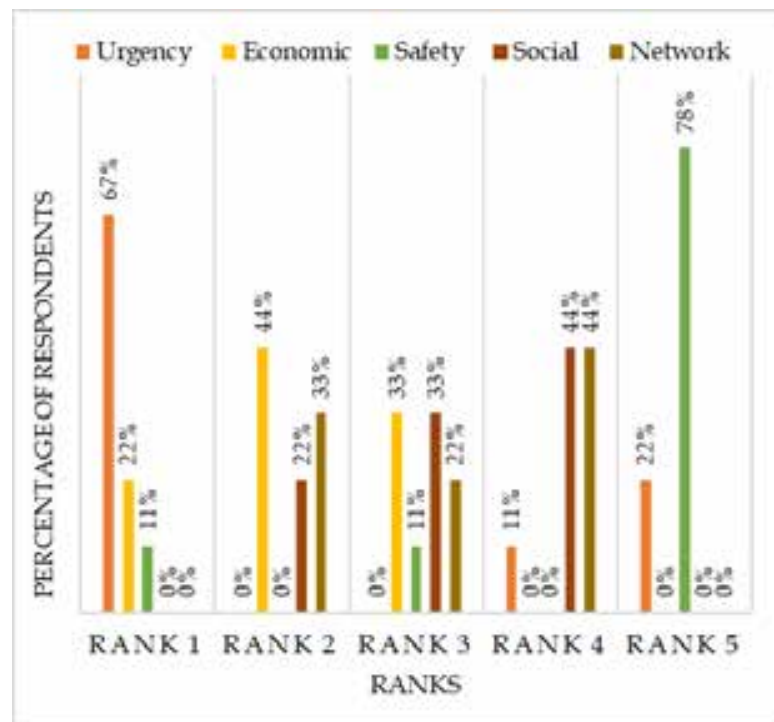

Figure 1 - Demand Criteria from Questionnaire Survey

For further analyses, using Garrett's ranking technique, all the ranks were converted to score values. The Garrett formula and Garrett's table were used to convert ranks into scores. Average score calculated for each criterion is shown in Table 1.

Table 1 - Average Score Each Demand Related Criterion

\begin{tabular}{|l|l|l|}
\hline No & Criterion & $\begin{array}{l}\text { Average } \\
\text { Score }\end{array}$ \\
\hline 1 & $\begin{array}{l}\text { Urgency of the project to } \\
\text { reduce congestion }\end{array}$ & 60.0 \\
\hline 2 & $\begin{array}{l}\text { National, regional economic } \\
\text { development }\end{array}$ & 60.2 \\
\hline 3 & Safety needs & 33.3 \\
\hline 4 & $\begin{array}{l}\text { National, regional social } \\
\text { benefits }\end{array}$ & 47.7 \\
\hline 5 & $\begin{array}{l}\text { Role of the road in network } \\
\text { development }\end{array}$ & 48.9 \\
\hline
\end{tabular}

\subsubsection{Financial Related Factors}

The percentage of respondents ranked each financial related criterion are presented in Figure 2. The following abbreviations are used in Figure 2.

Financial: Financial viability

Revenue: Long rang revenue potential from the project

Toll roads: Impact of project on viability of existing toll roads

Pricing: User pricing

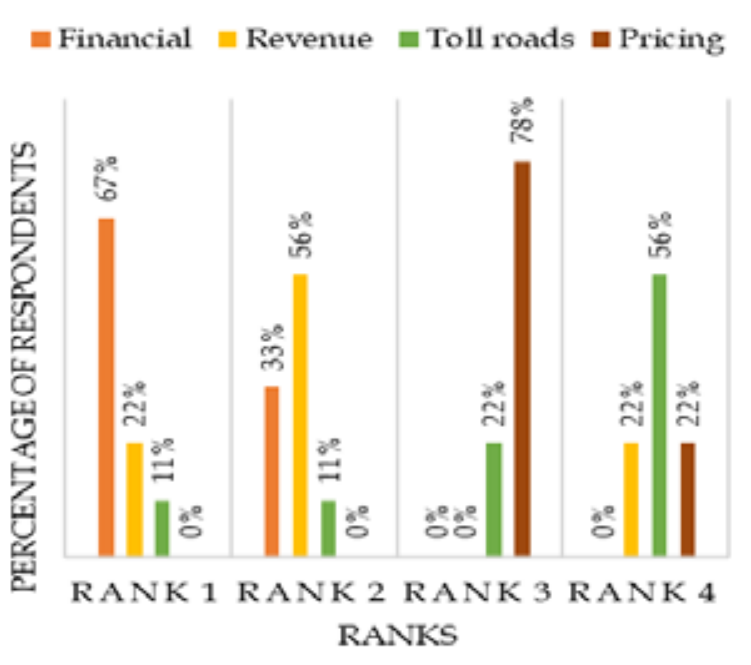

Figure 2 - Financial Criteria from the Questionnaire Survey Analysis

Garrett scoring technique was used to convert the rankings of financial criteria into score, and the average score is shown in Table 2.

Table 2 - Criterion Score using Garrett's Technique

\begin{tabular}{|l|l|l|}
\hline No & Criterion & $\begin{array}{l}\text { Average } \\
\text { Score }\end{array}$ \\
\hline 1 & Financial viability & 67.2 \\
\hline 2 & $\begin{array}{l}\text { Long range revenue potential } \\
\text { from the project }\end{array}$ & 53.5 \\
\hline 3 & User pricing & 40.1 \\
\hline 4 & $\begin{array}{l}\text { Impact of Project on viability } \\
\text { of existing toll roads }\end{array}$ & 39.3 \\
\hline
\end{tabular}

\subsubsection{Risk Related Factors}

The percentage of respondents ranked each risk related criterion as shown in Figure 3. The following abbreviations are used in Figure 3.

VfM: Value for Money from the project

O\&M: Transfer of significant Operational \& Management risk to Private team

Design: Design of the project to achieve best practice by PPP

Risk: Cost and Revenue risks

Land: Land acquisition

Resettlement: Resettlements

Environment: Project meeting environment safeguards 


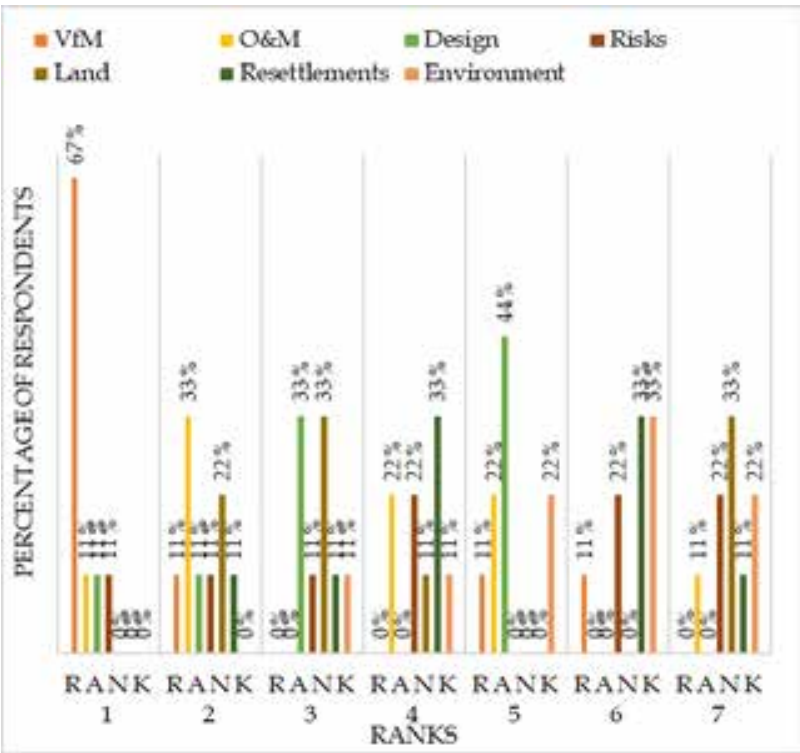

Figure 3 - Risk Criteria from Questionnaire Survey Analysis

Garrett scoring technique was used to convert the rankings of risk criteria into score as shown in Table 3 below.

Table 3 - Garrett Technique used for Risk Related Subpackage

\begin{tabular}{|l|l|l|}
\hline No & Criterion & $\begin{array}{l}\text { Average } \\
\text { Score }\end{array}$ \\
\hline 1 & $\begin{array}{l}\text { Value for Money from the } \\
\text { project }\end{array}$ & 68.2 \\
\hline 2 & $\begin{array}{l}\text { Transfer of significant } \\
\text { Operational \& Management } \\
\text { risk to Private team }\end{array}$ & 53.6 \\
\hline 3 & $\begin{array}{l}\text { Design of the project to } \\
\text { achieve best practice by PPP }\end{array}$ & 54.1 \\
\hline 4 & Cost and Revenue risks & 45.9 \\
\hline 5 & Land acquisition & 46.4 \\
\hline 6 & Resettlements & 44.2 \\
\hline 7 & $\begin{array}{l}\text { Project meeting environment } \\
\text { safeguards }\end{array}$ & 37.7 \\
\hline
\end{tabular}

\subsubsection{Project Scale Related Criteria}

The percentage of respondents ranks for each scale related criterion are given in Figure 4. The following abbreviations are used in Figure 4.

\section{Cost: Project Cost}

Scope: Project Functional Scope

Capability: Public Agency Capability in funding the project
Complex: Project Design and Construction complex

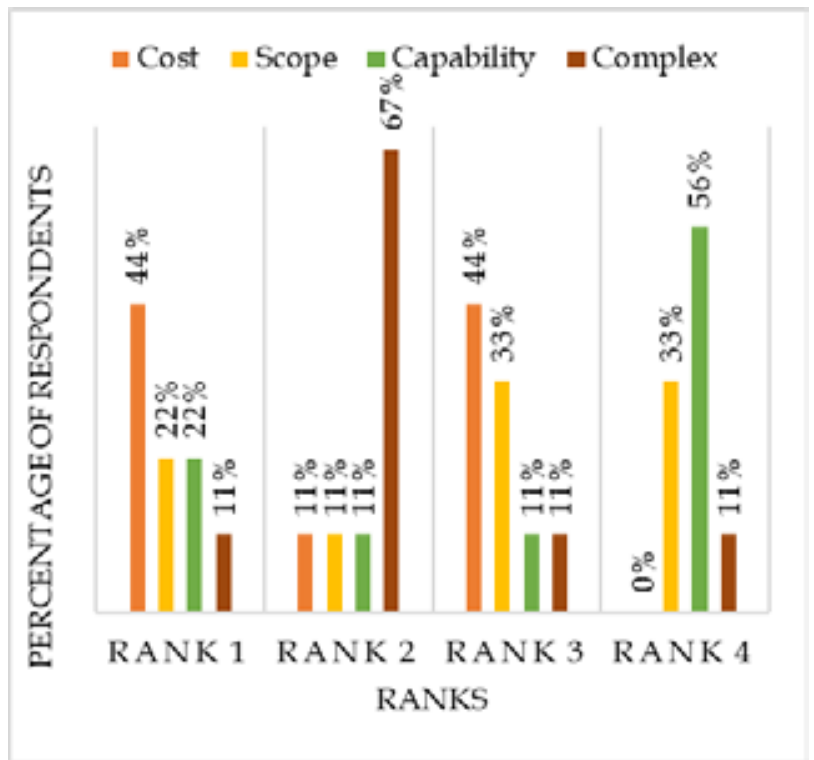

Figure 4 - Scale Criteria from the Questionnaire Survey Analysis

Table 4 used to presents the average score for each project scale related criterion using Garrett technique.

Table 4 - Garrett Technique used for Scale Related Subpackage

\begin{tabular}{|l|l|l|}
\hline No & Criterion & $\begin{array}{l}\text { Average } \\
\text { Score }\end{array}$ \\
\hline 1 & Project Costs & 57.9 \\
\hline 2 & $\begin{array}{l}\text { Project Design and } \\
\text { Construction complex }\end{array}$ & 53.5 \\
\hline 3 & Project Functional Scope & 46.1 \\
\hline 4 & $\begin{array}{l}\text { Public Agency Capability in } \\
\text { funding the project }\end{array}$ & 42.5 \\
\hline
\end{tabular}

\subsubsection{Ranking and Rating of Six Preferred} Criteria for Selection of Project

All the respondents were requested to select most important criteria from the twenty criteria and their suggestions if any. Further, respondents were requested to provide a 1-10 score for first six criteria they preferred. Purpose of the selection is to shortlist most important criteria for secondary screening. the percentage of the total score for the criteria divided the summation of score for all criteria was calculated in Table 5. 
Table 5 - Total Rating given for Criteria by Respondents

\begin{tabular}{|c|c|c|c|}
\hline & Criteria & TS & AS \\
\hline 1 & Financial viability & 71 & $17 \%$ \\
\hline 2 & $\begin{array}{l}\text { Value for Money from } \\
\text { the project }\end{array}$ & 52 & $12 \%$ \\
\hline 3 & $\begin{array}{l}\text { Long range revenue } \\
\text { potential from the } \\
\text { project }\end{array}$ & 42 & $10 \%$ \\
\hline 4 & $\begin{array}{l}\text { Transfer of significant } \\
\text { Operational \& } \\
\text { Management risk to } \\
\text { private team }\end{array}$ & 42 & $10 \%$ \\
\hline 5 & $\begin{array}{l}\text { National, regional } \\
\text { economic } \\
\text { development from the } \\
\text { project }\end{array}$ & 40 & $9 \%$ \\
\hline 6 & $\begin{array}{l}\text { Urgency of the project } \\
\text { to reduce congestion }\end{array}$ & 34 & $8 \%$ \\
\hline 7 & $\begin{array}{l}\text { Design of the project } \\
\text { to achieve best practice } \\
\text { by PPP }\end{array}$ & 22 & $5 \%$ \\
\hline 8 & Cost and revenue risks & 18 & $4 \%$ \\
\hline 9 & $\begin{array}{l}\text { Role of the road in } \\
\text { network development }\end{array}$ & 15 & $4 \%$ \\
\hline 10 & Project cost & 15 & $4 \%$ \\
\hline 11 & $\begin{array}{l}\text { Public agency } \\
\text { capability in funding } \\
\text { the project }\end{array}$ & 14 & $3 \%$ \\
\hline 12 & $\begin{array}{l}\text { Project design and } \\
\text { construction complex }\end{array}$ & 14 & $3 \%$ \\
\hline 13 & $\begin{array}{l}\text { National, regional } \\
\text { social benefits }\end{array}$ & 9 & $2 \%$ \\
\hline 14 & $\begin{array}{l}\text { Impact of project on } \\
\text { viability of existing toll } \\
\text { roads }\end{array}$ & 8 & $2 \%$ \\
\hline 15 & $\begin{array}{l}\text { Project functional } \\
\text { scope }\end{array}$ & 7 & $2 \%$ \\
\hline 16 & Resettlements & 6 & $1 \%$ \\
\hline 17 & $\begin{array}{l}\text { Project meeting } \\
\text { environment } \\
\text { safeguards } \\
\end{array}$ & 6 & $1 \%$ \\
\hline 18 & Safety needs & 6 & $1 \%$ \\
\hline \multirow[t]{2}{*}{19} & Land acquisition & 6 & $1 \%$ \\
\hline & & 427 & $100 \%$ \\
\hline
\end{tabular}

TS: Total score of the criteria

AS: \% of Total score for the criterial Aggregated total score for all criteria

\subsection{Preliminary and Secondary} Screening Criteria Selection

4.2.1 Criteria Shortlisted for Preliminary Screening with Suggested Indicators

Based on the Garrett's Ranking Score, the following criteria were selected for preliminary screening.

1. Urgency of the project to reduce congestion (PCU/day) and National, regional economic development from the project (EIRR)

2. Financial viability

3. Land acquisition (Percentage of the area expected to be acquired for the project)

4. Project cost (Project Cost Value)

\subsubsection{Secondary Screening Criteria}

The following nine (9) criteria were considered for secondary screening.

1. Financial viability - Maximum recommended score is 17

2. Long range revenue potential from the project - Maximum recommended score is 10

3. Transfer of significant Operational \&Management risk to private team Maximum score recommended is 10

4. National, regional economic development from the project - Maximum score recommended is 9

5. Urgency of the project to reduce congestion - Maximum score recommended is 8

6. Design of the project to achieve best practice by PPP - Maximum score recommended is 5

7. Cost and revenue risks - Maximum score recommended is 4

8. Role of the road in network development Maximum score recommended is 4

9. Project cost - Maximum score recommended is 4

\subsection{Applicability of Screening Criteria}

In this study, based on the questionnaire survey results and literature review, preliminary and secondary screening criteria were identified. But no threshold values were identified in this study. It is recommended to follow similar procedure to find preliminary and secondary criteria for any authority to 
develop screening criteria for highway PPP projects.

Appropriate threshold value for the indicators can be identified by the relevant authorities. For example, relevant authority could set an accepted value of FIRR for financial viability. Similarly, the relevant authorities could set a value for other indicators such as minimum $\mathrm{PCU} /$ day, EIRR, land acquisition requirement and minimum project cost.

\section{Comparison on Economic Evaluation of the Projects}

A case study was performed to compare the viability of existing expressway projects in Sri Lanka. In this study, for the comparison of projects, only the criteria identified for secondary screening were used. Due to nonavailability of qualifier threshold value for preliminary screening criteria, no projects were screened out using the preliminary screening.

\subsection{Scoring Criteria}

Based on the expert judgment from interviews, rating scales from respondents in the questionnaire survey, similar scores and weightages used in other guidelines, and scoring criteria, and maximum score developed. The scoring criteria for secondary screening is shown in Table 6.

Table 6 - Scoring Criteria

\begin{tabular}{|c|c|c|c|c|}
\hline & Project & Indicator & Scoring Criteria and Score & $\begin{array}{l}\text { Maximum } \\
\text { Score }\end{array}$ \\
\hline 1 & Financial viability & FIRR & $\begin{array}{l}\text { Very High: FIRR }>15 \%=17 \\
\text { High: } 10 \%<\text { FIRR }<15 \%=12 \\
\text { Medium: } 5 \%<\text { FIRR }<10 \%=8 \\
\text { Low: } 0 \%<\text { FIRR }<5 \%=4 \\
\text { Negative: FIRR }<0 \%=0\end{array}$ & 17 \\
\hline 2 & $\begin{array}{l}\text { National, regional } \\
\text { economic } \\
\text { development } \\
\text { from the project }\end{array}$ & EIRR & $\begin{array}{l}\text { Very High: } \text { EIRR }>25 \%=15 \\
\text { High: } 15 \%<\text { EIRR }<25 \%=10 \\
\text { Medium: } 12 \%<\text { EIRR }<15 \%=7 \\
\text { Low: EIRR }<12 \%=4\end{array}$ & 15 \\
\hline 3 & $\begin{array}{l}\text { Urgency of the } \\
\text { project to reduce } \\
\text { congestion }\end{array}$ & $\begin{array}{l}\text { Traffic number } \\
\text { expected after } \\
20 \text { years of } \\
\text { project opening }\end{array}$ & $\begin{array}{l}\text { Number of traffic attracted to a link } \\
\text { (PCU/day) } \\
\text { High: Over } 60,000=10 \\
\text { Medium: } 20,000-60,000=7 \\
\text { Low: Less than } 20,000=4\end{array}$ & 10 \\
\hline 4 & $\begin{array}{l}\text { Role of the road } \\
\text { in network } \\
\text { development }\end{array}$ & $\begin{array}{l}\text { Functional } \\
\text { importance of } \\
\text { the link }\end{array}$ & $\begin{array}{l}\text { Very high: If the link form national } \\
\text { integration or directly connects airport, } \\
\text { railway hub or port }=10 \\
\text { High: If link provides flexibility in route } \\
\text { selection or indirectly connects airport, } \\
\text { railway hub or port =7 } \\
\text { Medium: Link connect to a brand of } \\
\text { backbone transportation link = } 4 \\
\text { Low: Individual link =2 }\end{array}$ & 10 \\
\hline 5 & Project cost & Project cost & $\begin{array}{l}\text { High: Over USD } 200 \text { million }=10 \\
\text { Medium: USD } 100 \text { million to USD } 200 \\
\text { million = } 7 \\
\text { Low: Less than USD } 100 \text { million }=3\end{array}$ & 10 \\
\hline
\end{tabular}




\subsection{Project Details for Dcoring}

The project details are summarized in Table 7. The following abbreviations are used in Tables 7 and 8 . The score values of the projects which were selected for second screening are given in Table 8. It is assumed that all criteria have same weightages in decision making.

Thus, total score of the project can be calculated from individual scores.

CKE - Colombo - Katunayake Expressway

PAEP - Port Access Elevated Project

NKB Phase 1- NKB - Rajagiriya Elevated Project

NKB Phase 2 - NKB - Athurugiriya Elevated Project

SE - Southern Expressway
CE (M-K) - Central Expressway- Mirigama to Kurunagela Section

RE - Ruwanpura Expressway

OCH 3 - Outer Circular Highway Section 3

CE (M-K) - Central Express - Kadawatha to Mirigama Section

SEE - Southern Extension Expressway

ETA20 - Traffic number expected after 20 years of project opening

V.H - Very High

$\mathrm{H}$ - High

M - Medium

NV- Negative

Table 7 - Project Details

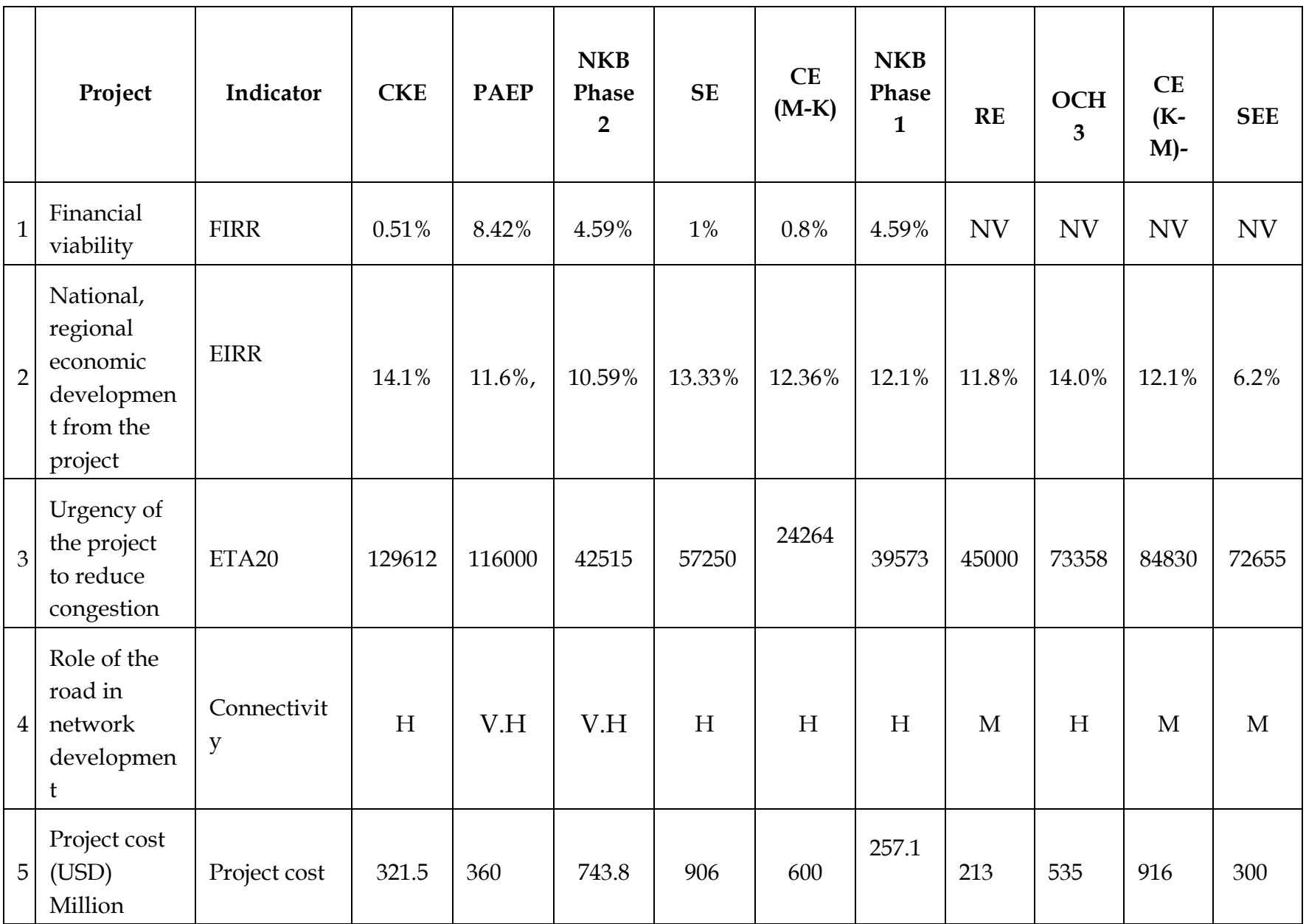


Table 8 - Project Score Based on Screening Criteria

\begin{tabular}{|c|c|c|c|c|c|c|c|c|c|c|c|c|}
\hline & Project & Indicator & CKE & PAEP & $\begin{array}{c}\text { NKB } \\
\text { Phase } \\
2\end{array}$ & SE & $\begin{array}{c}\mathrm{CE} \\
\text { (M- } \\
\mathrm{K})\end{array}$ & $\begin{array}{c}\text { NKB } \\
\text { Phase } \\
1\end{array}$ & RE & $\begin{array}{c}\mathrm{OCH} \\
3\end{array}$ & $\begin{array}{l}\text { CE } \\
\text { (K- } \\
\text { M)- }\end{array}$ & SEE \\
\hline 1 & $\begin{array}{l}\text { Financial } \\
\text { viability }\end{array}$ & FIRR & 4 & 8 & 4 & 4 & 4 & 4 & 0 & 0 & 0 & 0 \\
\hline 2 & $\begin{array}{l}\text { National, } \\
\text { regional } \\
\text { economic } \\
\text { development } \\
\text { from the } \\
\text { project }\end{array}$ & EIRR & 7 & 4 & 4 & 7 & 7 & 7 & 4 & 7 & 7 & 4 \\
\hline 3 & $\begin{array}{l}\text { Urgency of } \\
\text { the project to } \\
\text { reduce } \\
\text { congestion }\end{array}$ & ETA20 & 10 & 10 & 7 & 7 & 7 & 7 & 7 & 10 & 10 & 10 \\
\hline 4 & $\begin{array}{l}\text { Role of the } \\
\text { road in } \\
\text { network } \\
\text { development }\end{array}$ & Connectivity & 7 & 10 & 10 & 7 & 7 & 7 & 4 & 7 & 4 & 4 \\
\hline 5 & $\begin{array}{l}\text { Project cost } \\
\text { (USD) }\end{array}$ & Project cost & 10 & 10 & 10 & 10 & 10 & 10 & 10 & 10 & 10 & 10 \\
\hline & Score & & 38 & 42 & 35 & 35 & 35 & 35 & 25 & 34 & 31 & 28 \\
\hline
\end{tabular}

From the scoring of projects in Table 8, Port Access Elevated Project can be selected as best PPP viable project in Sri Lanka. Other criteria which are not included in the secondary screening also endorsing the project as follows.

- Private land acquisition of the project is zero since the land belongs to Ports Authority.

- There are any direct resettlements from the project.

- The project is not passing through an environmentally sensitive trace.

- The project can bring positive impact to other expressways such as NKBAthurugiriya, Colombo-Katunayeke.

\section{Discussion}

The findings of the study could help to screen potential PPP projects in Sri Lanka. Further, the relevant selection criteria which could be considered were identified. This preliminary and secondary screening will help to screen out unviable PPP projects and focus on potential PPP projects.
For screening of PPP projects, the information should be collected from the following analysis.

1. Economic analysis

2. Financial analysis

3. Risk analysis

4. Technical analysis

5. Market analysis

6. Environmental analysis

7. Stakeholder analysis

8. Institutional analysis

9. Value for Money analysis

\subsection{Limitations of the Research}

The questionnaire survey was carried out from only on nine (9) respondents. Non availability of PPP and highway background experts was one of the limitations to select respondents.

In this research, no qualifier was identified for preliminary screening criteria indicators. For the elimination of projects using preliminary screening criteria, threshold values need to be identified. 
After the secondary screening, there should be a minimum threshold score for selection of projects. The purpose of this threshold value is to make sure that no unqualified projects are being selected in the screening process.

From the literature review of other guidelines, it is learned that it is important to identify weightage score for each criterion. Since the importance of the criteria is different for each criterion, weightage can be used to represent that in decision making. But, in this study all the criteria were given equal weightage.

Major limitation in this study is that there are not successfully completed PPP road projects in Sri Lanka, to compare our study with the real-world project scenario.

In addition, another limitation was the lack of availability of detailed documentation in the projects.

\subsection{PPP Project Constraints in Sri Lanka}

The constraints in Sri Lanka for acceleration of PPP projects were identified from literature review and interviews. This information will help to develop any documents related to PPP such as guidelines.

1. One of the constraints to adopt PPP in Sri Lanka is unstable political environment and frequent policy changes. So, it would be difficult to adopt PPP projects with political risks. For example, New KelaniAthurugiriya Elevated Road was under concessionaire selection stage in 2019, but after the change of government this project was termed as an unsolicited project.

2. Investors are not motivated with subsidies. Preferential tax policies need to be established to attract private partners.

3. The bankability of projects is a crucial problem for Sri Lankan PPP projects.

4. Due to urgency of the projects with political reasons, PPP is not considered in SL. Availability of loans (Even with high interest rate) with grace period demotivates PPP in SL.

5. There is no legal infrastructure in the country for private partnerships including procurement method.

6. Unsolicited projects are given high priority than solicited projects. While analyzing the PPP projects in Sri Lanka, unsolicited proposals are a big hurdle to carryout best PPP practices in the country. For example, for Northern Expressway, the FNPV calculated for stage 1 Colombo - Mirigama and Stage 2 Mirigama - Kurunagela was 739 million by China Merchants Group (4) where, these calculations were carried out the prospective private party. So, the reliability of the revenue and estimations may not be credible. Thus, unsolicited projects may reduce the benefits of PPP. The Unsolicited projects need to be treated with Swiss Challenge Model.

7. Absence of Toll related policy in Sri Lanka.

8. The affordability to pay tolls is key issue in setting user charges. The Willingness to Pay survey can be used in user charge determination.

9. In Sri Lanka, revenue of the expressway is only expected from the tolls. When a region does not achieve the expected growth after the project, the toll revenue cannot be obtained as expected in the studies. Thus, it can cause the projects to fail when that region very much depends on the revenue for future economic development of the region.

10. The uncertainty in traffic estimation prevails due to change in political proposals. For example, a change in public transportation policy can change the traffic numbers. Developed countries have more long-term plans than developing countries. This makes it difficult to estimate for more than 10 years for developing countries.

\section{Research Findings}

\subsection{Development of Screening Criteria}

From the questionnaire survey analysis, a better representing criterion was selected to represent demand, financial, risk and scale subpackages. These criteria were used to develop pre-screening criteria. The following preliminary screening criteria were shortlisted.

1. Urgency of the project to reduce congestion

2. National, regional economic development from the project

3. Financial viability

4. Land acquisition

5. Project cost

Further, nine (9) secondary screening criteria were shortlisted for selection of candidate PPP projects. Secondary criteria and suggested 
scores are given below in the ranking order by respondents.

1. Financial viability - Maximum recommended score is 17

2. Long range revenue potential from the project - Maximum recommended score is 10

3. Transfer of significant Operational \& Management risk to private team Maximum score recommended is 10

4. National, regional economic development from the project - Maximum score recommended is 9

5. Urgency of the project to reduce congestion - Maximum score recommended is 8

6. Design of the project to achieve best practice by PPP - Maximum score recommended is 5

7. Cost and revenue risks - Maximum score recommended is 4

8. Role of the road in network development Maximum score recommended is 4

9. Project cost - Maximum score recommended is 4

Financial viability of the project was identified as a key criterion for selection of PPP projects. FIRR can be used to identify financial viability of projects. The long-range revenue potential can be represented by $\mathrm{PV}$ of the revenue during the operation period. The transfer of Operational and Management risk can be indicated by risk in monetary terms, transferred to private party from PPP arrangement. The Nation, regional, economic development can be represented by EIRR or $\mathrm{BCR}$ of the project.

Furthermore, to represent demand of the project urgency, reduction in traffic congestion can be used. PCU/day can be used to identify this criterion. Design of the project to achieve best practice by PPP is represented by qualitative indicators. Construction complexity of the project can be used to represent the criteria.

Cost and revenue risks are identified as a key failure factor. Thus, projects that come up with more cost and revenue risk should be excluded from PPP candidate list. Role of the particular project in the road network is considered as a criterion in the secondary screening. The national integration from the project can be considered in screening by including the criterion. Functional importance of the road can be used to indicate the criterion.

Whereas Project cost can be considered as a scale representing criterion, in Sri Lanka, due to the preparation involved in PPP, the threshold value for PPP project is set as USD 50 Million.

Even though land acquisition and resettlements are considered as a key PPP project failure factor, from the questionnaire analysis it was evident respondents felt it was not the most important criteria. The reason for this was found in the interview that with existing laws and regulation in the country, land acquisitions can be managed by the institution.

User charges was not selected as a top six factor by any respondents. Since this can be decided by the management, with a proper willingness to pay for survey, appropriate charges can be determined. Currently there is no toll road related policy available in Sri Lanka. This makes it difficult for user charge evaluation for projects.

Value for Money (VfM) analysis is recommended to be carried out in the final screening due to the data required for the analysis. There are many tools to analyze VfM analysis. Public Sector Comparator and Shadow Bid Model tools were used by NAPPP.

Project readiness was included in the existing two-phase selection method in Sri Lanka. Conceptual level project will have less information compared to detailed designed project. This criterion is included in Phillippines guideline as well.

\subsection{Comparison of Completed, Ongoing and Future Projects as PPP Candidate}

From the total score of the project Port Access Elevated Highway (42/62 score) is the best candidate road of all the considered projects and could have been considered as a candidate PPP project.

\section{Recommendation}

Identification of qualifiers for indicators of preliminary screening criteria of urgency of the project to reduce congestion (PCU/day) and national, regional economic development from the project (EIRR), financial viability (FIRR), land acquisition (percentage of the total project land need to be acquired from 
private parties), project cost (project cost) is recommended for further study.

A threshold score is recommended to identify projects after secondary screening. A qualifier threshold score value will help to select only good projects after screening.

Weightages for each criterion should be studied and developed for the better screening of projects.

\section{References}

1. Redup, O., (2019). Identification, Selection and Prioritization of PPP projects. Streamlining the implementation of PPP. Colombo.

2. Zhang, X., (April 2004). Concessionnaire Selection : Methods and Criteria. Journal of Construction Engineering and Management, 235-244.

3. Dhanavandan, S., (2016). "Application of Garrent Ranking Technique". International Journal of Library and Information Studies, 135140.

4. (2013). Nothern Expressway Project Stages $1 \mathcal{E} 2$ (Colombo-Kurunagela Expressway). China Merchants Group. 